\title{
The promises and realization of the right to development in the Democratic Republic of the Congo
}

\author{
By Balingene KAHOMBO*
}

\begin{abstract}
This paper examines, from a legal and socio-economic perspective, how the right to development materializes its promises and realization in the Democratic Republic of the Congo (DRC). In this regards, it analyzes its incorporation in the Congolese legal order, defines its constituent elements, and the measures which have been adopted to implement the constitutional framework. It also identifies challenges to the right to development in the DRC and permissive conditions for its effective enjoyment. The main conclusion is that the right to development enshrined in the Congolese law remains more a matter of claims and aspirations than a tangible reality reflecting an increase in the quality of life of the Congolese people. Obstacles to the realization and enjoyment of the right to development include the adverse effects of capitalist liberalism, the extraversion of Congolese development policies, and the culture of predation which dates back to the colonial period. The Congolese leadership has a historic responsibility to trigger or impose the much needed change. This will require not only the integration of the DRC's international commitments in its domestic development policies based on an internal dynamic putting Congolese at the center of every socio-economic initiative, but also a state which has effective authority over its territory to defend the rule of law, is more interventionist so as to stop the current intentional destruction of the country, and promotes ethical behaviours in public services.
\end{abstract}

\section{A. Introduction}

This study does not re-assess existing theories which conceptualize the right to development in international law but examines how this right materializes its promises and realization as a consequence of different implementation public policies in the Democratic Republic of the Congo (DRC). It is a legal and socio-economic analysis of the right to development as a human and people's right under the Congolese legal order.

To begin with, three major points are held to be true. First, the right to development is a human right whose legal existence is no longer contested. The doctrinal invention of the notion has been attributed to the late Senegalese scholar and former judge at the International Court of Justice (ICJ), Keba M'Baye, following his historic conference held in 1972

* Dr. iur. (Free University of Berlin/Germany), Associate Professor/Law Department, University of Goma; Researcher/Centre for Research and Studies on the Rule of Law in Africa (CREEDA), Democratic Republic of Congo (DRC). E-mail: balingene82@gmail.com; balingenek@creedardc.org 
at the Institute des Droits de l'Homme de Strasbourg (France). ${ }^{1}$ Although narratives on the bases of the right to development had evolved over the years, it was referred to as such in various United Nations (UN) documents at the end of the $1970 \mathrm{~s}^{2}$ In particular, the UN General Assembly adopted its resolution 34/46 of 23 November 1979 emphasizing "that the right to development is a human right and that equality of opportunity for development is as much a prerogative of nations as of individuals within nations". ${ }^{3}$ Second, unlike many other human rights which originate from domestic legal orders before their extension in international law, the right to development has been conceived first at the international level. It emerges from claims by newly independent states in 1960s for genuine equality and justice as well as end of neocolonialism in international economic relations, and progress for all peoples. ${ }^{4}$ These claims gave a rise to a new discipline of public international law, named international law of development. ${ }^{5}$ However, the African continent was the first to include the right to development in a multilateral treaty, i.e. the African Charter on Human and Peoples' Rights (hereafter African Charter) of $1981 .{ }^{6}$ Then, the right to development received a worldwide recognition through the adoption of the Declaration on the right to development of $1986,{ }^{7}$ and the Final Declaration of the Vienna Conference on human rights in $1993 .{ }^{8}$ As a consequence of these efforts, the UN envisages, after the African continent, the conclu-

1 See Keba M'Baye, "Le droit au développement comme un droit de l'homme", Revue des Droits de l'Homme, vol.5 (2-3), 1972, pp.503 - 534. See also Jean-Paul Segihobe Bigira, « Le pas perdu de l'Afrique dans la promotion des droits de solidarité », in Oswald Ndeshyo (ed), Le nouvel élan du panafricanisme, l'émergence de l'Afrique et la nécessité de l'intégration continentale-Les actes des journées scientifiques consacrées à la commémoration de la journée de l'Afrique : 2011-20122013-2014, Kinshasa, Editions Cedesurk, 2015, p.114.

2 United Nations Social and Economic Council, Report of the Secretary-General: The international dimensions of the right to development as a human right in relation with other human rights based on international co-operation, including the right to peace, taking into account the requirements of the new international economic order and the fundamental human rights, Commission on Human Rights, Thirty-fifth session, Agenda item 8 of the provisional agenda (E/CN.4/1334, 2 January 1979, p.29; Tamara Kunanay, "The Declaration on the Right to Development in the Context of United Nations Standard-Setting", in United Nations Human Rights Office of the High Commissioner, Realizing the Right to Development: Essays in Commemoration of 25 Years of the United Nations Declaration on the Right to Development, New-York and Geneva, UN, 2013, pp.17-65.

3 UNGA Res. 34/46, 23 November 1979: Alternative approaches and ways and means within the United Nations system for improving the effective enjoyment of human rights and fundamental freedoms, para.8.

4 Alain Pellet, Le droit international du développement, $2^{\text {nd }}$ edn., Paris, Presses universitaires de France, 1987, pp.3 - 4 .

5 Oscar Schachter, "The Evolving Law of International Development", Columbia Journal of Transnational Law, vol.15 (1), 1976, p.10.

6 African Charter on Human and Peoples' Rights (27 June 1981), articles 22 and 24.

7 UNGA Res.41/128, 4 December 1986: Declaration on the Right to Development.

8 Vienna Declaration and Programme of Action (A/CONF.157/23, excerpted from DPI/1394/Rev.1/ HR-95-93241, April 1995, on the World Conference on Human Rights, 14 - 25 June 1993), para.10. 
sion of a binding universal treaty on the matter that is being prepared by the Human Right Council Working Group on the Right to Development. ${ }^{9}$ Third, like many human rights, the right to development has an international, regional and national dimension. This study focuses on the national dimension only in the context of the DRC's legal order.

Theoretically development connotes the idea of progress in various domains: political, legal, economic, social and cultural. The concept is therefore multidimensional. However, its socio-economic aspects are by far prevalent because they are the ones which largely affect every person's daily life. Taking into account this aspect of the matter, the UN General Assembly recalls that "the achievement of lasting progress in the implementation of human rights is dependent upon sound and effective national and international policies of economic and social development". ${ }^{10}$ If development implies progress, the enjoyment of the underlying right is instead predictive and futuristic rather than being necessarily a present reality. ${ }^{11}$ How is the right to development incorporated in the Congolese legal order? What is its scope therein? Which efforts have been deployed for its implementation and to which extent they have succeeded or failed? What might be the permissive conditions for the effective realization of the right to development in the DRC?

These questions can be answered using two different perspectives. On the one hand there is a micro approach to the right to development which is atomic, individualistic and based on particular cases brought to justice. This perspective is inherently legalistic and juridical. On the other hand, there is a macro approach to the right to development which rather focuses on the collective dimension as a people's right which is promoted on the basis of the right to self-determination and state sovereignty over its natural resources. It is a policy-based approach which endeavours to scrutinize macro-efforts made within a state for the realization of the right to development. This study takes into account both approaches but gives primacy over the second one so as to have a consistent overall picture on the framework and the context in which the DRC is implementing, thanks to its socio-economic policies, its duty regarding the respect and the realization of the right to development. In other words, it is an interdisciplinary study but court's decisions enforcing this right are not the main focus of the discussion for they deserve a separate analysis.

It is argued that the Congolese positive law translates -like international law -claims and aspirations for development. The law has attributed to various stakeholders diverse

9 See Zamir Akram, "Draft Convention on the Right to Development, with commentaries", Human Rights Council Working Group on the Right to Development Twenty-first session 4-8 May 2020 Item 4 of the provisional agenda, Review of progress made in the promotion and implementation of the right to development (A/HRC/WG.2/21/2/Add.1), 20 January 2020.

10 UNGA Res.32/130, 16 December 1977: Alternative approaches and ways and means within the United Nations system for improving the effective enjoyment of human rights and fundamental freedoms, para.1(b).

11 Alain Pellet, "Le «bon droit » et l'ivraie -Plaidoyer pour l'ivraie (Remarques sur quelques problèmes de méthode en droit international du développement), in Le droit des peuples à disposer d'eux-mêmes -Méthodes d'analyse du droit international : mélanges offerts à Charles Chaumont", Paris, A. Pédone, 1984, pp. $470-472$. 
roles in realizing development. They must work to improve not only economic growth but also the quality of individual and collective lives. This requirement has to be viewed as a consequence of the persistent gap between the DRC's potential, the increase in under-development and the poverty of its people. Still, tremendous challenges are preventing efforts made from achieving social justice and human welfare.

Therefore, section 2 describes the Congolese law's conception of the right to development from its incorporation in the DRC's legal order in the 1990s. Section 3 analyses the implementation policy of this legal framework and suggests that a partnership for development has been put in place. Section 3 demonstrates why the rules laid down and the policies adopted to implement them have not so far produced positive results. Section 4 finally identifies some permissive conditions for overcoming current challenges to the right to development and its effective enjoyment in the DRC.

\section{B. The Congolese law's conception of the right to development}

States do not have the same conception of the right to development under their municipal laws. Peculiarities are incorporated so as to adapt the legal framework to context and realities. The pattern which is described by the Congolese law has been shaped under the influence of several factors of domestic and international origin. The definition of the right to development follows from the dynamic of crises and armed conflicts since the 1990s, as well as rules of international law applicable in the DRC.

\section{The path of legalization efforts following crises and armed conflicts}

The DRC has a tradition of affirming human rights in its constitutions. ${ }^{12}$ However, the constitutional declarations of rights are not identical. Some constitutions contain broader declarations than others. Their evolution has always been dictated by the dynamic of domestic affairs and political system. None of the DRC's constitutions incorporated the right to development until the 1990s. The first constitutional text to have done this is the Harmonized Constitutional Act Relating to the Period of Transition of $1993 .{ }^{13}$ Its article 13 (2) specifically provided that each Congolese had the right to development. This individualistic conception was repeated in similar words in the Constitutional Act of Transition of 1994. ${ }^{14}$ The reasons why the 1990s have marked the initial incorporation of the right to development in the Congolese legal order are twofold. First, the evolution follows from the DRC's acces-

12 See Marcel Wetsh'okonda Koso Senga, Les textes constitutionnels congolais annotés, Kinshasa, Editions de la Campagne pour les Droits de l'Homme au Congo, 2010.

13 Law No.93 - 001 of 2 April 1993 laying Down the Harmonized Constitutional Act Relating to the Period of Transition (Official gazette, special issue, April 1993).

14 Constitutional Act of Transition of 4 April 1994, article 12 (2). 
sion to the African Charter of 1981 in July $1987 .{ }^{15}$ Second, this period corresponds to the time of the second wave of democratisation after the initial experience of the 1960s which was finally stopped by a coup d'état in $1965 .{ }^{16}$ This re-democratization followed several decades of one-party regime which had been imposed by former president Joseph Mobutu. This was the consequence of popular claims for democratic governance and the end of the cold war which led to Mobutu being abandoned by his Western allies who were no longer willing to support a dictator. A transition was organised to lead the country to pluralist elections. In this context, constitutions were successively adopted to heal the political system from its existing sins. Among these were the havoc of a kleptomaniac government. The Sovereign National Conference (1991-1992), convened in an effort to democratize the country, acknowledged that Mobutu's predations included embezzlement, spoliation and plundering of resources, theft and extortionat the expense of the people. ${ }^{17}$ Under-development, poverty and misery became the common fate of all Congolese. The fact that constitutions this time incorporated the right to development had two potential advantages. On the one hand, it raised the level of protection of this right in the domestic legal order. On the other hand, it appears that constitutional protection had a higher psychological effect than a treaty provision of which existence could be in fact ignored by the majority of politicians and people due to a poor circulation of legal information.

However, constitutions seemingly prioritized a conception of the right to development based socio-economic aspects. This infrastructural conception was subsequently reinforced and improved. The first step was made by the Ministry of Human Rights in 2001. The latter convened the National Conference on Human Rights which, by the end, produced a nonbinding document, named the Congolese Charter on Human and People's Rights. ${ }^{18}$ Among other innovations, it proclaimed the inalienable and inviolable character of the right of Congolese people to development with two major implications. ${ }^{19}$ One of these is the right of each Congolese or group of citizens to oversee the management of resources allocated for the individual and collective welfare, and the other one is the people's right to dispose freely of their natural resources. ${ }^{20}$ The justification of this evolution is tied to the DRC

15 African Union, 'List of countries which have signed, ratified/acceded to the African Charter on Human and People's Rights' (15 June 2017)< https://au.int/sites/default/files/treaties/36390-sl-afric an_charter_on_human_and_peoples_rights_2.pdf $>25$ September 2020.

16 Célestin Kabuya Lumuna Sando,"Le processus de democratisation en Afrique: le cas de la République Démocratique du Congo", in Augustin-Romain Kioni Kiabantu (ed.), La République Démocratique du Congo face aux défis du XXIè siècle -Hommage au professeur Michel Norro, Bruxels, Academia/Bruylant, 1998, p.93. See also Georges Nzongola-Ntalaja, The Congo from Leopld to Kabila: A People's History, London and New York, Zed Books, 2007, pp.95 - 96.

17 DRC, Conférence Nationale Souveraine: Rapport de la Commission de Biens Mal Acquis (DRC 1992), p.7.

18 DRC, Actes de la Conférence Nationale sur les Droits de l'Homme, vol.II, Kinshasa, Ministère des Droits Humains, 2001, pp.9-36.

19 Congolese Charter on Human and People's Rights (2001), article 8 (1).

20 Ibid., article 8 (1) and (2). 
falling into appalling armed conflicts between 1993 and 2003. ${ }^{21}$ In particular, the armed conflict which had started in August 1998, and commonly known as the first truly African World War due to the huge number of direct belligerent parties, namely eight African states $^{22}$ as well as numerous non-state actors, made the DRC to become an environment that could be pillaged with impunity: among other things, natural resources were plundered and banks, state companies and private properties, looted. Congolese officials, rebel groups, foreign states, arms traffickers and multinational corporations were all involved. Many of these crimes were documented by the Congolese parliament as well as the UN Panel of Experts on the Illegal Exploitation of Natural Resources and Other Forms of Wealth of the DRC, created in $2000 .^{23}$ Some were also acknowledged by the International Court of Justice and the African Commission on Human and Peoples' Rights. ${ }^{24}$

The Congolese Charter on Human and People's Rights was suggested to parliament to be adopted in the form of a legislative act. ${ }^{25}$ But, delegates to the Congolese peace dialogue, held in Sun City and Pretoria (South Africa) so as to put an end to the protracted armed conflicts, preferred the tradition of incorporating the declaration of human rights in the constitutions. The 2003 Constitution of Transition therefore acknowledged the right to development to Congolese people and it belonged to the state to guarantee its respect. This provision has been literally replicated in the 2006 Constitution which is nowadays in

21 See Office of the United Nations High Commissioner for Human Rights, 'Democratic Republic of the Congo, 1993-2003: Report of the Mapping Exercise Documenting the Most Serious Violations of Human Rights and International Humanitarian Law Committed within the Territory of the Democratic Republic of the Congo between March 1993 and June 2003' (August 2010), <http://w ww.ohchr.org/Documents/Countries/CD/DRC_MAPPING_REPORT_FINAL_EN.pdf $>25$ September 2020.

22 These were the DRC, Angola, Namibia, Chad, Zimbabwe, Rwanda, Burundi and Uganda.

23 See DRC, Assemblée Nationale: Commission Nationale Spéciale Chargée de l'Examen de la Validité des Conventions à Caractère Economique et Financier Conclus pendant les Guerres de 19961997 et de 1998: Rapport des Travaux: Première Partie (DRC, 26 June 2005) <www.droitcongola is.info/files/rapport_lutundula.pdf> accessed 22 September 2020; UN Security Council, 'Report of the Panel of Experts on the Illegal Exploitation of Natural Resources and Other Forms of Wealth of the Democratic Republic of the Congo' S/2001/357 (12 April 2001); UN Security Council, 'Final Report of the Panel of Experts on the Illegal Exploitation of Natural Resources and Other Forms of Wealth of the Democratic Republic of the Congo' S/2002/1146 (16 October 2002); UN Security Council, 'Final Report of the Panel of Experts on the Illegal Exploitation of Natural Resources and Other Forms of Wealth of the Democratic Republic of the Congo' S/2003/1027 (23 October 2003).

24 Armed Activities on the Territory of the Congo (Democratic Republic of the Congo v Uganda), Judgment of 19 December 2005, ICJ Reports 2005, para.345(4); Democratic Republic of Congo $v$ Burundi, Rwanda and Uganda, ACmHPR, Comm. 227/1999, $20^{\text {th }}$ Activity Report (January-June 2006), paras.94 and 96-98.

25 DRC, note 18, p.8. See also Balingene Kahombo, "The Democratic Republic of Congo's National Human Rights Commission", in Charles M. Fombad (ed.), Compendium of documents on National Human Rights Institutions in eastern and southern Africa, Pretoria, Pretoria University Law Press, 2019, p.106. 
force. ${ }^{26}$ It must be implemented by the legislature and other branches of the government. Before looking at this aspect, it is important to specify the scope of constituent elements of the right to development and see to which extent they have been influenced by international law.

\section{The international law influence on the definition of constituent elements}

International law is relevant to the definition of constituent elements of the right to development in the Congolese legal order for two main reasons. First, the RDC is part of the monist legal tradition. ${ }^{27}$ As a consequence, the legal framework governing the right to development includes international treaties duly ratified and published in the official gazette. Of particular importance is the African Charter to which the preamble of the 2006 Constitution also refers. ${ }^{28}$ This implies that the stipulation of the right to development by this treaty is part of the Congolese law and, moreover, the interpretation of the same right enshrined in the Congolese Constitution must be made in light of the African Charter and all interpretative materials provided by the African Commission and Court on Human and Peoples' Rights. Secondly, the DRC's 2006 Constitution does not clearly define the right to development. All of what it incorporates contains three aspects. Above all, article 58 (2) proclaims the right to development. It also places the duty to guarantee its respect on the Congolese state. Article 58(1) tied to the aforementioned paragraph 2 then appears to acknowledge the right to development for the benefit of all Congolese by providing that they have the right to enjoy their national wealth. As such the right to development is quoted in chapter 3 of title II of the Constitution among collective rights constitutionally protected. It is a people's right. The term people must be understood broadly in conjunction with articles 22 and 24 of the African Charter on the right to development so as to extend its meaning, as clarified by regional jurisprudence, ${ }^{29}$ to the population of the entire continent, the entire population of a state, an ethnic group or minority or any other homogenous population with a common identity. ${ }^{30}$ However, under the 2006 Constitution, the right to development is reserved for Congolese only. This regime is therefore lower than that provided for by the African Charter, inasmuch as beyond Congolese, other groups of foreign origin may also qualify as peoples and have an entitlement to enjoy the right to development in the DRC. The 2006 Con-

26 Constitution (18 February 2006) as revised (20 January 2011), article 58(2).

27 Ibid., articles 153(4) and 215. See also Balingene Kahombo, "The Principle of Complementarity in Practice: A Survey of Congolese Legislation Implementing the Rome Statute of the International Criminal Court", in Beitel van der Merwe and Gerhard Kemp (eds.), International Criminal Justice in Africa, 2016, Nairobi, Strathmore University Press, 2017, pp.210 - 211.

28 Constitution (18 February 2006) as revised (20 January 2011), preamble, para.6.

29 See Katangese Peoples' Congress v. Zaire, ACmHPR, Comm.75/92, 8 Activity Report (19941995), paras.2 and 6.

30 Rachel Murray, The African Commission on Human and Peoples' Rights and International Law, Oxford, Hart Publishing, 2000), p.105. 
stitution is nevertheless an improvement of the legal language compared to the wording of previous constitutions of the 1990s which proclaimed only an individual right to development for the benefit of each Congolese. As mentioned earlier, the provision has been replicated from the 2003 Constitution of Transition. Now the collective and individual dimensions certainly converge to some point because as the African Commission on Human and Peoples' Rights stated in the Kilwa case, the declaration of a collective right does not prevent the exercise of that right by individuals. ${ }^{31}$

The question arises as to the scope of the substance given to the right to development. As explained above, the 2006 Constitution underlined socio-economic aspects of the right to development. It does not include the political dimension as ascertained in the UN Declaration on the right to development, ${ }^{32}$ nor does it contain the cultural aspect to which the African Commission on Human and Peoples' Rights alluded in its decision in the case Democratic Republic of Congo v. Burundi, Rwanda and Uganda.$^{33}$ In particular, attacks on cultural values protected, such as the funeral rites of the populations, violate that said right. $^{34}$

Still even with respect to the socio-economic dimension of the right to development, the 2006 Constitution does not provide for a clear definition. An attempted definition can tie the term right to the concept of development. In fact, there are different conceptions of development. Walter Rodney distinguishes three types of development: personal development, development at the level of social groups and economic development. In his view, personal development implies "increased skill and capacity, great freedom, creativity, selfdiscipline, responsibility, and material well-being". ${ }^{35}$ Instead, development at the level of a social group connotes the idea of "increasing capacity to regulate both internal and external relationships", ${ }^{36}$ which entails that a social group has strengthened its ability to safeguard its own independence. ${ }^{37}$ As to economic development, Walter Rodney writes: "A society develops economically as its members increase jointly their capacity for dealing with the environment. This capacity for dealing with the environment is dependent on the extent to which they understand the laws of nature (science), on the extent to which they put that understanding into practice by devising tools (technology), and on the manner in which work is organized". 38

31 Institute for Human Rights and Development in Africa and others v. Democratic Republic of Congo, ACmHPR, Comm.393/10, 41 ${ }^{\text {st }}$ Activity Report (May -November 2016), para. 142.

32 UNGA Res.41/128, 4 December 1986: Declaration on the Right to Development, article 1.

33 Democratic Republic of Congo v. Burundi, Rwanda and Uganda, note 24, para. 87.

34 Institute for Human Rights and Development in Africa and others v. Democratic Republic of Congo, note 31, para.143.

35 Walter Rodney, How Europe Underdeveloped Africa, with a postscript by A.M. Babu, Washington, Howard University Press, 1982, p.3.

36 Ibid.

37 Ibid., p.4.

38 Ibid. 
It is evident that these three types of development combines the individual and collective dimensions. Moreover, they suggest that no development can be achieved if a social group like a state lacks independence, for example if it is under colonial or neocolonial domination. Similarly, there is no development if a given state does not increase its capacity based on science, technology and modernization of working conditions.

Walter Rodney's conception corrects the deficiency of the other definition of development which some economic scholars, such as Rostow, have equated with economic growth. ${ }^{39}$ Yet, this quantitative approach may signify nothing if it is not accompanied by a qualitative and social conception of development. The concept now implies at least that economic growth is reflected in the improvement of the quality of life of the population, such as access to resources, education, water, electricity, sanitary and justice. ${ }^{40}$ This is also the understanding of the UN working Group on the right to development. ${ }^{41}$ But indicators that a group develops would become meaningless if over the time the other characteristics of development specified by Walter Rodney are missing, namely independence, science, technology and modernization of working conditions favorable to the respect of workers' human rights.

Overall, the right to development must be understood in light of the aforementioned clarifications. As to its socio-economic aspects which constitute the sole element which the DRC's 2006 Constitution underscores, put aside the political and cultural dimensions based on international law, the following definition can be suggested: the right to development is an individual and a collective prerogative of the people and each of the citizens of a state, which is sovereign and politically independent, to enjoy the material and social benefits of economic growth of their nation, science and technology, which implies access to resources, equitable distribution of wealth and the qualitative improvement of individual lives as well as of collective welfare. In accordance with article 60 of the 2006 Constitution, the right to development is binding and imposes itself on public authorities and any person (public or private) being on the territory under the DRC's jurisdiction. ${ }^{42}$ The manner in which the Congolese state endeavours to guarantee its respect is a matter of different public policies formalized by the Constitution, different laws and regulations. These policies are reflective of a partnership for the realization of the right to development in the DRC.

\section{The implementation policy based on a partnership for development}

To discharge a part of its obligation for the realization of the right to development in the $\mathrm{DRC}$, the Congolese state has shared roles to different stakeholders and even imposes fur-

39 Walt Whitman Rostow, The Stages of Economic Growth: A Non-Communist Manifesto, Cambridge, Cambridge University Press, 1960, pp.4 - 17.

40 Balingene Kahombo, "Les activités minières et le respect des droits de l'homme au Kivu", Recht in Afrika - Law in Africa -Droit en Afrique, vol.22, 2019, p.210.

41 Akram, note 9, p.7.

42 Kahombo, note 40, p.207. 
ther duties on them as well as rights for the Congolese people. This policy translates the idea that a partnership between different actors has been prescribed so as to achieve the common goal of development. This partnership reserves a role for public-private sectors and includes the social responsibility of enterprises.

\section{The role of public-private sectors}

The Constitution provides that the DRC is a social state. ${ }^{43}$ This provision is the central justification of the role that the state should play to guarantee the right to development. In this regard, the DRC is to be an agent of development. This role is executed at different levels of the exercise of public authority, mainly the central government (executive and national parliament), provinces, decentralized territorial entities (cities, municipalities, sectors and chiefdoms) and public enterprises and establishments. As such, the DRC is a welfare state which is expected to be interventionist contrary to the opposite model of a gendarme state. What it has to do as an agent of development contains three main aspects that deserve to be underlined.

The first one relates to the duty of the state itself to participate in the realization of the right to development. In this regard, the DRC is obligated to share equitably the country's national wealth. ${ }^{44}$ This is implemented through two distinct legal mechanisms. On the one hand, the obligation to share the national revenue as prescribed by the 2006 Constitution, i.e. in the ratio of 60 per cent for the central government and 40 per cent for provinces. ${ }^{45} \mathrm{On}$ their side, provinces should turn their 40 per cent into 100 per cent with 40 per cent allocated to decentralized territorial entities, ${ }^{46}$ which constitute the DRC's local governments. ${ }^{47}$ This mechanism is part of the vertical technique of separation of power based on the protection of the financial autonomy of provinces and local governments which have the powers to undertake their specific developmental initiatives without waiting for the action of the central government. ${ }^{48}$ It also means that the latter is now forbidden to monopolize the state resources because, as demonstrated in the past, this monopolization has led, through cor-

43 Constitution (18 February 2006) as revised (20 January 2011), article 1 (1).

44 Ibid., article 58 (2).

45 Ibid., article 175 (2).

46 Organic Law No.08/016 of 7 October 2008 Relating to the Composition, Organization and Functioning of the Decentralized Territorial Entities and their Relationships with the State and Provinces, article 115.

47 Joseph Cihunda Hengelela, "Decentralized Territorial Entities and Promotion of Local Governance under the Constitution of 18 February 2006 in the Democratic Republic of the Congo", in in Charles M Fombad and Nico Steytler (eds), Decentralization and Constitutionalism in Africa, Oxford University Press, 2019, p.369 and 371.

48 Paulin Punga Kumakinga, "Autonomie financière des provinces et problématique du principe constitutionnel de la retenue à la source de $40 \%$ des recettes à caractère national : essai d'évaluation à mi-parcours", in Jean-Michel Kumbu Ki Ngimbi (ed.), La décentralisation territoriale en République démocratique du Congo sous le régime de la Constitution du 18 février 2006 : bilan et 
ruption and embezzlement, to illicit enrichment of members of successive kleptomaniac central governments instead of improving the well-being of the Congolese people. ${ }^{49}$ The situation tends to be reversed in a way that development should primarily be realized at the lower levels of the exercise of public authority. This should prevent a generalized mismanagement of the country as in the previous times of autocratic governments and dictatorship.

The logic of providing provinces and local governments with sufficient resources to initiate or support their development policies is extended to the funds generated by the exploitation of the DRC's natural resources, such as forests and minerals. For example, the Mining Code of 2002 as revised in 2018 provides that royalties paid by holders of exploitation titles must be shared in the ratio of 50 per cent for the central government, 25 per cent for the province concerned, and 15 per cent for the city or territory where such exploitation takes place, with the remaining 10 per cent reserved for the Mining Fund created for the welfare of future generations of Congolese. ${ }^{50}$ Similarly, royalties paid against forest concessions must be shared in the ratio of 60 per cent for the central government and 40 per cent for "decentralized territorial entities". ${ }^{51}$ It is worth noting that at the time the Forest Code was promulgated in 2002, provinces were among such entities contrary to the 2006 Constitution which has raised them to the status of politically organized entities in the framework of constitutional regionalism. ${ }^{52}$ Overall, the result is to be the same: current regionalized provinces and decentralized territorial entities will share 40 per cent of royalties allocated to them by the Forest Code.

On the other hand, the plundering of natural resources is criminalized, that is to say "any act, agreement, convention, arrangement or other fact which results in the deprivation of the nation, natural or legal persons of all or part of their own livelihoods derived from their resources or from their natural resources, without prejudice to international provisions on economic crimes". ${ }^{53}$ The 2006 Constitution even specifies that this constitutes the crime of high treason if committed or attempted by a public authority. ${ }^{54}$ But when implementing

perspectives, Kinshasa, Edition de la Campagne pour les droits de l'homme au Congo, 2014, pp. $135-143$.

49 Balingene Kahombo, "Corruption and its Impact on Constitutionalism and Respect for the Rule of Law in the Democratic Republic of the Congo", in Charles M Fombad and Nico Steytler (eds.), Corruption and Constitutionalism in Africa: Revisiting Control Measures and Strategies, Oxford University Press, 2020, pp.290 - 293.

50 Law No. 007/2002 Relating to the Mining Code as Modified and Complemented by Law No. 18/001 of 9 March 2018 (11 July 2002), article 242.

51 Law No.011/2002 of 29 August 2002 Laying down the Forest Code, article 122 (1).

52 Balingene Kahombo, "Regionalism under the Congolese Constitution of 18 February 2006: Progress and Challenges", in Charles M Fombad and Nico Steytler (eds), Decentralization and Constitutionalism in Africa, Oxford University Press, 2019, pp.193 - 198.

53 Constitution (18 February 2006) as revised (20 January 2011), article 56. See also Law No. 007/2002 Relating to the Mining Code as Modified and Complemented by Law No. 18/001 of 9 March 2018, article 311 ter.

54 Ibid., article 57. 
this constitutional framework, the legislature has failed to take into account such an official capacity. First in the definition of the crime of high treason for which the President of the Republic and the Prime Minister can be held responsible before the Constitutional Court. ${ }^{55}$ As a consequence, when these authorities are suspected of having plundered the DRC's natural resources, their behaviour can be prosecuted only as an ordinary offence. In terms of criminal policy, the difference is significant because the crime of high treason is punishable by life imprisonment, ${ }^{56}$ whereas, pursuant to article 311 ter of the Mining Code as revised in March 2018, for example, the ordinary offence of pillaging mining resources is sentenced with ten up to twenty years in prison and a severe fine. Second in the definition of the crime of pillaging mining resources, which implies that if the aforementioned official capacity is proven, it would be taken in account as a "judicial aggravated circumstance"57 allowing the competent jurisdiction to apply to the perpetrator the maximum of the punishment provided for by the law.

The second aspect of intervention of the Congolese state as an agent of development relates to the implementation of sectorial development policies. This is the case with the function assigned to the creation of public enterprises. ${ }^{58}$ These economic entities are meant to provide basic socio-economic services to people, such as in the sectors of water and electricity distribution. It is also the case with the mobilization of international cooperation -bilateral or multilateral -for development. Traditional partners of the DRC include the World Bank and the International Monetary Funds (IMF). ${ }^{59}$ Currently, for example, the World Bank is funding in three years the governmental programme of free primary education for up to USD 800 million. ${ }^{60}$ But cooperation is not only interstate, bilateral and multilateral; there is also a transnational aspect which proceeds from the conclusion of a partnership with private investors supporting domestic efforts to achieve development. The DRC's Federation of Companies (Fédération Congolaise des Entreprises-FEC) emphasized on the inescapable character of such a partnership in a memorandum to parliamentarians in

55 Organic Law No.13/026 of 15 October 2013 Relating to the Organization and Functioning of the Constitutional Court, articles 73 and 74.

56 Ibid., article 75.

57 Nyabirungu mwene Songa, Traité de droit pénal général congolais, 2ème édition, Kinshasa, Editions Universitaires africaines, 2007, p. 399.

58 See Law No.08/010 Determining the Rules on the Organisation and the Management of State Companies (7 July 2008); Lukombe Nghenda, Le Droit des Entreprises Publiques, Né de la Réforme du 7 Juillet 2008 (Publication des Facultés de Droit des Universités du Congo 2009).

59 Oswald Ndeshyo, "Coopération bilatérale et multilatérale", in Facultés Catholiques de Kinshasa, Quelle économie pour le Zaïre? Actes du IXème Séminaire scientifique -Kinshasa, du 03 au 06 mai 1996, Kinshasa, Etudes publiées par la Faculté des Sciences et Techniques de Développement, 1996, pp. $417-440$.

60 World Bank, "Press Release: The World Bank Supports Free Primary Education and Maternal and Child Health Improvements in the DRC" (15 June 2020)<https://www.worldbank.org/en/news/pre ss-release/2020/06/15/the-world-bank-supports-free-primary-education-and-maternal-and-child-he alth-improvements-in-the-drc> 30 September 2020. 
$2010 .^{61}$ This reinforces the basis of the policy of attraction of private investments and improvement of the business environment which the successive central governments have pursued since at least 2001. ${ }^{62}$ The 2006 Constitution has legitimized this policy in providing that the "state shall encourage and ensure the security of private, national and foreign investment". ${ }^{63}$ It has been among the dominant aspect of neoliberalism as the underpinning economic ideology through which the DRC has been persuaded by international partners and is expecting to realize development. ${ }^{64}$

The third and final aspect illustrates how the state and private investors can work jointly on the ground. Joint action is a matter of public-private partnership which is governed by the law of July $2018 .^{65}$ In practical terms, the partnership can take two major forms. On the one hand, the state in its different levels of the exercise of public authority (central government, provinces, decentralized territorial entities, public enterprises and establishments) can associate private economic actors to their efforts to realize development through mechanisms of public procurements. ${ }^{66}$ The most common procurements are made up of delegations of public services whereby, in this case, the state or its branches confer the management of public service on a private actor or investor. ${ }^{67}$ On the other hand, joint action is possible through the conclusion of a partnership contract relating to the conception, construction, exploitation or maintenance of public or private infrastructures belonging to the state. ${ }^{68}$ This kind of partnership may even concern the management of natural resources. ${ }^{69}$

All in all, the state bears the principal responsible for every aspects pertaining to the realization of the right to development. It has its duties, but other functions are allocated to private economic actors or investors, and different levels of the exercise of public authority. The legal regimes which govern this vast field of socio-economic development are very complex; but it belongs to the state to ensure that the rules that have been laid down are complied with so as to execute its own obligation to guarantee the right to development under the 2006 Constitution. These legal regimes range from constitutional and administrative law, such as the law on public procurements, to investment law, the laws on natural resources and international law of cooperation. Given the very limited scope of this study, only a short outline is given on the specificity of the social responsibility of enterprises.

61 Balingene Kahombo, "L'adhésion de la RDC à l'OHADA: vers la prospérité nationale par l'unification du droit? ", Librairie africaine d'études juridiques, vol.11, juillet 2012, pp.106 - 107.

62 Ibid., pp.105- 106.

63 Constitution (18 February 2006) as revised (20 January 2011), article 34 (3).

64 Kahombo, note 40, pp.221 - 222.

65 Law No.18/016 of 9 July 2018 Relating to Public-Private Partnership.

66 See Law No. 10/010 on Public Markets (27 April 2010).

67 Law No.18/016 of 9 July 2018, note 65 , article 3.

68 Ibid.

69 Ibid., article 4. 


\section{The social responsibility of enterprises}

There is a debate about the extent to which companies and mainly transnational corporations shall comply with human rights obligations. Different regimes are applicable when they commit human rights violations. First, there are well-known instances whereby states have been held responsible for their failure to protect against human rights violations committed by corporations. ${ }^{70}$ Second, state responsibility can be invoked for acts committed by companies under the conditions set out by the International Law Commission (ILC) Draft Articles on State Responsibility of $2001 .{ }^{71}$ Third, companies can be held directly responsible for their human rights violations. Practice is now in favour of their accountability for failure to comply with due diligence obligations which require enterprises to check, in all their activities, if their actions do not contribute to human rights violations. ${ }^{72}$ Still legislation is also evolving. If the respect for human rights is not an obligation under an international instrument, the duty upon companies is based on domestic law, sometimes in implementation of international law. This is actually the case with rules on the social responsibility of enterprises.

In the DRC, companies that are bound by the regime of social responsibility have to participate in municipal efforts for the realization of the right to development. The concept of social responsibility of enterprises must however be distinguished from the accountability of companies. By definition, accountability implies that companies are required to comply with the law in the conduct of their businesses or face legal consequences. ${ }^{73}$ The notion is broader and not judicial by nature. It may entail judicial, political, diplomatic, administrative and economic sanctions. These may be the consequence of the failure to carry out the social responsibility of enterprises. In its Opinion of April 2019, in regard to the mining and forest sectors, the DRC's National Human Rights Commission (Commission nationale des droits de l'homme-CNDH) indicated that the social responsibility of enterprises encompasses the duty of companies to integrate into their managerial policy not only

70 Matthias Herdegen, Principles of International Economic Law, Oxford, Oxford University Press, 2013, pp. $102-106$.

71 See James Crawford, Brownlie's Principles of Public International Law, 8th edn., Oxford, Oxford University Press, 2012, p.122.

72 See Norms on the Responsibilities of Transnational Corporations and Other Business Enterprises with Regard to Human Rights, U.N. Doc. E/CN.4/Sub.2/2003/12/Rev.2 (2003); OECD Guidelines for Multinational Enterprises (2011); Tripartite Declaration of Principles concerning Multinational Enterprises and Social Policy, adopted by the Governing Body of the International Labour Office at its $204^{\text {th }}$ Session (Geneva, November 1977) and amended at its $279^{\text {th }}$ (November 2000), 295 (March 2006) and 329 ${ }^{\text {th }}$ (March 2017) Sessions; UN Global Compact: Corporate Citizenship in the World Economy (2008); Regulation (EU) 2017/821 of the European Parliament and of the Council of 17 May 2017 laying down supply chain due diligence obligations for Union importers of tin, tantalum and tungsten, their ores, and gold originating from conflict-affected and high-risk areas.

73 Andrew Clapham, "Non-State Actors", in Daniel Moeckli, Sangeeta Shah, Sandesh Sivakumaran and David Harris (eds), International Human Rights Law, Oxford, Oxford University Press, 2014, p.541. 
the improvement of the life and working conditions of their staff, but also the promotion of the development of the areas in which they operate by carrying out some socio-economic activities, such as building roads, hospitals and schools. ${ }^{74}$ The concept is particularly relevant in the area of exploitation of natural resources, such as in the mining, oil and forest sectors. ${ }^{75}$

The social responsibility of enterprises is therefore an important tool for the protection of the right to development of local communities, that is, those which are situated in regions where companies deploy their activities. In substance, the concept of local community refers to "the population traditionally organized on the basis of custom and united by the bonds of clan or parental solidarity which bases its internal cohesion". ${ }^{76}$ It is also characterized by its attachment to the territory affected by the company's project. ${ }^{77}$

The duty of companies to initiate and fund basic infrastructural development projects for the benefit of local communities is to be clarified in details in the conditions of contracts these companies sign with the state. Its scope however varies from one enterprise to another, and depending on the sector of intervention. For example, in the mining sector, companies are required to spend 0.3 per cent of their year's revenue on development projects. ${ }^{78}$ In addition, local communities benefit an array of rights, namely, the right to repairs in the event of displacement orchestrated by the mining project, the right to resettlement in a space that allows to reach a higher standard of living than the home environment, the right to participation and information required for the entire compensation and resettlement process, as well as the right to remedy and appeal. ${ }^{79}$

Thus, mechanisms to implement the right to development in the DRC are numerous; but it remains to be seen if they produce positive results on the ground. The truth is that the realization of the right to development in DRC is very limited.

74 Avis No.005/AP/CNDH -RDC/2019 -Avis et Propositions de la Commission Nationale des Droits de l'Homme (CNDH) sur la Responsabilité Sociétale des Entreprises d'Exploitation Forestière et Minière en République Démocratique du Congo, 15 April 2019, p.5.

75 Kahombo, note 40, p.211; Paulin Punga Kumakinga, "La gestion du secteur forestier en République Démocratique du Congo: esquisse du bilan de la réforme de 2002 à partir de l'exemple de la province de l'Equateur", Librairie africaine d'études juridiques, vol. 15, 2013, pp. 11-13. See also Law No.15/012 of 1 August 2015 on the General Oil Regime.

76 Law No.18/001 of 9 March 2018 Modifying and Complementing the Law No.007/2002 of 11 July 2002 Laying down the Mining Code, article 1 (9 quinquies); Law No.011/2002 of 29 August 2002 Laying down the Forest Code, article 1(17).

77 Ibid.

78 Law No. 007/2002 Relating to the Mining Code as Modified and Complemented by Law No. 18/001 of 9 March 2018, articles 258bis and 285 octies.

79 Decree No.038/2003 of 26 March 2003 Relating to the Mining Regulation as Modified and Complemented by the Decree No.18/024 of 8 June 2018, Annexe XVIII, Chapter II, articles 4-8. 


\section{The limited level of realization}

There is a paradox between the law laid down, the scope of policies conceived to carry out the rules, the potentials on which these policies rely, namely the Congolese human capital and natural resources, on the one hand, and the grave situation of under-development in the DRC as well as the misery of its people on the other. The question then arises as to the reasons for this situation and which permissive conditions can be suggested to change it.

\section{The reasons for the lack of effective right to development}

The DRC is still one of the poorest countries in the world. The annual income per capita has been estimated at $\$ 565$ in $2018,{ }^{80}$ meaning that Congolese overall leave with less than two American dollars per a day. The Congolese do not benefit from their national wealth; instead, underdevelopment and poverty have reached alarming proportions. The Bertelsmann Foundation reported in 2016 with terms which are still pertinent today as follows:

According to the World Bank, $31 \%$ of Congolese have access to sanitation facilities and $47 \%$ to water sources (2012); however, these numbers are much lower in rural areas. Schooling in rural areas is either extremely deficient or lacking altogether. In many conflict-ridden parts of the country, access to health infrastructure is nonexistent; if there are health facilities, most are not provided by the government but by private and/or humanitarian organizations. Even large cities, such as Bukavu in South Kivu, have no fire brigades or government-run ambulances. Major reconstruction programs, including Kabila's promised "cinq chantiers" and the Stabilization and Reconstruction Plan for DRC (STAREC), have produced very limited results. ${ }^{81}$

Further, reporting on the same issue in 2020, the Foundation indicated that the DRC made no substantial progress between 2017 and 2019.82 Poverty is still widespread, and "The country has missed all the Millennium Development Goals (MDG) and its ranking in the Human Development Index (HDI) has been stuck at 176 out of 188 countries since 2016". ${ }^{83}$

The situation has been worsened due to Covid-19 pandemic. It is well known that the $\mathrm{DRC}$ is rich of numerous minerals, such as cobalt, copper, coltan and gold. Some of these

80 African Statistical Yearbook (2019), p.87.

81 Bertelsmann Foundation, "BIT 2016: Congo, DR Country Report" (Bertelsmann Foundation 2016), p.9<www.bti-project.org/fileadmin/files/BTI/Downloads/Reports/2016/pdf/BTI_2016_Co ngo_DR.pdf $>$ accessed 30 September 2020. 'Cinq Chantiers' was the name given to President Kabila's programme for the DRC's development in 2006. Its five aspects related to the improvement of access to education, employment, water and electricity, and basic infrastructure such as roads, hospitals, schools and airports.

82 Bertelsmann Foundation, "BIT 2020 Country Report: Congo, DR" (Bertelsmann Foundation 2020), p.4 <https://www.ecoi.net/en/file/local/2029559/country_report_2020_COD.pdf $>30$ September 2020.

83 Ibid., p.15. 
minerals are strategic for the world economy. The case has an adverse effect in that it makes the DRC's economy dependent on the international market as minerals form nearly 80 per cent of Congolese exports. ${ }^{84}$ The Congolese government has foreseen not only the reduction of direct foreign investments in the country, but also of budgetary resources due to the decrease of mineral exports by 20.6 per cent in 2020 to countries (China, member states of the European Union and the United States of America) heavily affected by the pandemic that form the major poles of the world economy. ${ }^{85}$ It must be kept in mind that the fall of economic growth as a consequence of this situation must drastically affect conditions of employment in the public and private sectors. There is a great risk of increasing the rate of unemployment and reducing the value of employees' poor salaries.

As it may be seen, the current context is not favourable to the right to development. However, there are three other main reasons why efforts made to achieve the right to development have not so far yielded positive results.

First is the ideological driver of development. The Congolese state has produced numerous laws which are based on capitalist liberalism. ${ }^{86}$ Interventionism as it could have been materialized from the conception of a welfare state has in fact declined. This has something to do with history, in so far as, since its inception as the Congo Free State in 1885 , the DRC has been called to be open for all foreign nations in equality for the purpose of freely doing business and making money. ${ }^{87}$ The legal framework, based on the General Act of the Berlin Conference, ${ }^{88}$ was precisely qualified as the regime of "open doors" (portes ouvertes) ${ }^{89}$ The continuation of liberalism after independence reflects the same logic of openness of the country to the world economic affairs. The problem is that liberalism is less profitable to Congolese who do not have sufficient assets to compete against powerful protected foreign investors. All strategic sectors of the Congolese economy are by far held by foreigners: banks, big commercial enterprises, mining, oil and forest industries, etc.

84 World Bank, "République Démocratique du Congo: Rapport de Suivi de la Situation Economique et Financière 2015 - Troisième Edition. Renforcer la Résilience de Long Terme de la RDC: le Rôle de la Dédollarisation, de la Prospection Artisanale et de la Diversification Economique", World Bank, September 2015, p.10.

85 DRC, "Impacts sanitaires et socio-économiques de la COVID-19 en République Démocratique du Congo : Analyse prospective et orientations de la riposte multisectorielle", Kinshasa, May 2020, p.16.

86 Kahombo, note 40, pp.221 - 222.

87 Jean-Paul Segihobe, Le Congo en droit international: essai d'histoire agonistique d'un Etat multinational, Bruxelles, Presses universitaires Ryckmans, 2011, pp.84 - 85.

88 General Act of the Conference at Berlin of the Plenipotentiaries of Great Britain, Austria-Hungary, Belgium, Denmark, France, Germany, Italy, The Netherlands, Portugal, Russia, Spain, Sweden and Norway, Turkey and the United States Respecting: (1) Freedom of Trade in the Basin of the Congo; (2) The Slave Trade; (3) Neutrality of the Territories in the Basin of the Congo; (4) Navigation of the Congo; (5) Navigation of the Niger; and (6) Rules for Future Occupation on the Coast of the African Continent (26 February 1885), articles 1-5.

89 Balingene Kahombo, "L'adhésion de la RDC à l'OHADA: vers la prospérité nationale par l'unification du droit?", Librairie Africaine d'Etudes Juridiques, vol.11, July 2012, p.105. 
The liberalization trend has attained a wild proportion as no socio-economic sector, including public enterprises, is spared from foreign investors to the extent that Congolese people have no control over their economy. The situation of neoliberalism problematically makes the DRC a source of extraction of resources for money generated by the constellation of foreign investors is not kept in the DRC to support its development initiatives. This has been, for example, one of the major controversial issues in the lucrative mining sector since $2002 .{ }^{90}$ Whereas the law imposed on all foreign investors to keep 40 per cent of their export revenues in the $\mathrm{DRC},{ }^{91}$ the central government usually complained against illicit flows of capitals due to a systematic disregard of the law in force. ${ }^{92}$ This has led to the revision of the Mining Code, which not only raises to 60 per cent the amount of export revenues to be kept in the DRC, but also now provides for huge financial penalties in case of non-compliance. ${ }^{93}$ To be optimistic that the new legal framework would be applied requires overcoming the companies' resistance against the law. They simply do not want to comply with the Mining Code despite reminders from the central government. ${ }^{94}$

Second is the consequence of the first reason: the extraversion of national policies for development. Congolese are not much implicated in the dynamic of development. There is no industrialization policy to boost not only the Congolese participation in development initiatives but also local production of goods for national consumption. The central government places its hopes into money being fuelling in the DRC by its economic partners, such as the IMF and the World Bank, and foreign investors. Yet, as it is well known, each people is responsible for its development. Development cannot be bestowed from outside but is the result of municipal sacrifices. International cooperation can only complement these efforts.

The adverse effect of relying too much on foreign assistance is twofold. On the one hand, the DRC does not have full control over the resources provided in order to allocate them to projects which correspond to its priorities. This often leads to dilapidation with no realistic end in terms of development approach. On the other hand, as assistance is not provided only as donation but also in terms of international loans, the DRC increases its external debts with little domestic capacity to reimburse. There are also fears to pay back more than what has been received due to the capitalization of interests. The DRC has a consistent

90 Kahombo, note 40, p.224.

91 Law No.007/2002 of 11 July 2002 Laying down the Mining Code, article 269 (b).

92 Kahombo, note 40, p.224.

93 Law No.18/001 of 9 March 2018 Modifying and Complementing the Law No.007/2002 of 11 July 2002 Laying down the Mining Code, article 309bis.

94 Jordan Mayenikini, "RDC : les miniers qui ne rapatrient pas $60 \%$ des recettes d'exportation dans le collimateur du gouvernement" (27 July 2020) <https://deskeco.com/2020/07/27/rdc-les-miniersqui-ne-rapatrient-pas-60-des-recettes-dexportation-dans-le-collimateur> 4 October 2020; Amédée Mwarabu, "RDC : les miniers non en règle ont 15 jours pour rapatrier la quotité de $60 \%$ des recettes d'exportation (Conseil des ministres)" (29 August 2020) <https://deskeco.com/index.php/20 20/08/29/rdc-les-miniers-non-en-regle-ont-15-jours-pour-rapatrier-la-quotite-de-60-des-recettes $>4$ October 2020. 
bad experience with this as a heritage of former President Mobutu's governance. ${ }^{95}$ Foreign debts reached worrying proportions of up to USD 13.7 billion of which use was not traceable in the country. ${ }^{96}$ The DRC was obliged to follow the special programme reserved for heavily indebted poor countries under the leadership of the aforementioned financial institutions for the purpose of getting a substantial reduction of its foreign debts. This was achieved in 2010, which brought the latter down to USD 2.931 billion. ${ }^{97}$ The continuation of extraversion policies is therefore a recipe of the past which has already demonstrated its limits. It is impoverishing instead of enabling development in the DRC.

Third, there is a persistent culture of predation in the DRC. State resources are largely monopolized by politicians. Politics is considered to be a lucrative business through embezzlement, corruption and illicit enrichment. This does not enable to translate the good intentions embedded in successive development plans into real positive results. President Félix Tshisekedi has published his own plan, named National Strategic Plan for Development, which is designed to be executed during his five-year term (2019-2023). However, the plan has to be funded with USD 47.55 billion. ${ }^{98}$ Just for this financial reason, it may not be successful because, for one thing, the DRC has made it clear that it could mobilize USD 21.84 billion of the total budget only, of which 11.99 per cent could be provided by its partners. ${ }^{99}$ Thus, 54.07 per cent of the needed budget is lacking and still to be found. ${ }^{100}$ As long as state resources and money go into private pockets, it would be naïve to be optimistic that the new plan can reach its development goals.

Predation has become a cancer which affects all socio-economic sectors. For example, the equitable share of national wealth as prescribed by the Constitution and different laws is not complied with. ${ }^{101}$ Provinces and decentralized territorial entities are financially asphyxiated; their capacity to sustain development initiatives included in President Tshisekedi's plan is largely compromised. In the same vein, companies do not complied with their obligations based on the social responsibility of enterprises. In its investigation report released in 2019 on the issue with respect to the mining and forest sectors in four provinces (HautLomami, Eastern Kasai, Lualaba and Tshopo), the CNDH has found that -with the complicity of corrupt state officials, mainly political authorities in Kinshasa -companies not only fail sometimes to pay taxes but also to participate in the development of socio-economic

95 Joseph Cihunda Hengelela, "Aide de la Banque mondiale à la République Démocratique du Congo : Problème de gestion, responsabilité des acteurs et perspectives d'avenir", Librairie Africaine d'Etudes Juridiques, vol.11, July 2012, pp.40 - 41.

96 Paulin Punga Kumakinga, "Les interventions du Fonds monétaire international en République Démocratique du Congo : base juridique, bilan et perspective", Librairie Africaine d'Etudes Juridiques, vol.11, July 2012, p.65.

97 Ibid., p.66.

98 DRC, "Plan national stratégique de développement (2019-2023)", Kinshasa, 2019, p.87.

99 Ibid., p.88.

100 Ibid.

101 Kahombo, note 52, p.206. 
infrastructures (hospitals, schools, water supplies, roads, etc.) for the benefit of the local communities of the place where they deploy their activities. ${ }^{102}$ In other words, investors and corrupt politicians are enriching themselves at the expense of Congolese people, contributing therefore to underdevelopment.

This picture enables to question the perspective of the right to development in the DRC. Something must be done to change the situation or to prevent it from worsening.

\section{The permissive conditions for the realization of the right to development}

As demonstrated above, there are several constraints which hinder the realization of the right to development in the DRC. They must be overcome. Three further conditions can be taken into account as being conditions of which satisfaction may facilitate the respect for the right to development by the state and any person pursuant to the 2006 Constitution.

To begin with, it is imperative to stop the current situation of 'statocide'103 -intentional destruction by instability, armed conflict, pillaging and corruption. Efforts in this regard should be accompanied by state re-building, starting with the establishment of an efficient administration from the capital city to villages. ${ }^{104}$ Re-building the state also implies the strengthening of the justice system in order to tackle the impunity gap and systematic disregard of the laws. These efforts aims at reinforcing the state authority over the entire territory as no development is possible in disorder or a chaotic situation.

There is also a need to integrate the DRC's international commitments in domestic development policies based on an internal dynamic putting Congolese at the center of every socio-economic initiative. These commitments can be found in various instruments produced by international organizations of which the DRC is member such as the African Union (AU). For example, the 2003 AU Declaration on agriculture and food security in Africa provides that member states agree to adopt sound policies for agricultural and rural development and to allocate at least 10 per cent of national budgetary resources for their implementation. ${ }^{105}$ Likewise, in the field of education, science and technology, AU member

102 See National Commission on Human Rights, "Rapport Ponctuel d'Enquêtes sur la Responsabilité Sociétale des Entreprises d'Exploitation Forestière et Minière en République Démocratique du Congo (15 April 2019)", Kinshasa, 2019.

103 Ntumba Luaba Lumu, "De l'usage abusif de l'argument de dénocide face à la tentative de statocide", in Faculté de Droit de l'Université de Kinshasa, La guerre d'agression contre la République Démocratique du Congo et l'Interpellation du droit international-Actes des Journées de Réflexion du 5 au 6 Octobre 1998, Kinshasa, Presses Universitaires de Kinshasa, 1999, p.41.

104 See Jean Otemikongo Mandefu Yahisule, RDC : administrer l'Etat selon les règles de l'art. Impératifs pour une administration publique congolaise du développement, Paris, L'Harmattan, 2020.

105 Assembly/AU/Decl.7 (II), Declaration on agriculture and food security in Africa, $2^{\text {nd }}$ Ordinary Session, AU Assembly, Maputo (Mozambique), 10-12 July 2003, para.2. See also Balingene Kahombo, "L’Union africaine et la République démocratique du Congo: l'état de relations en 2011 et leur prolongation en 2012", in Oswald. Ndeshyo (ed.), Mélanges Célestin Nguya-Ndila. La Ré- 
states agree to invest 1 per cent of their Gross Domestic Production (GDP) in research and development, and 4 to 6 per cent in education. ${ }^{106}$ These are indicators of good governance at the domestic level. They put human resources in the heart of development policies: they must be well nourished and educated in order to participate efficiently in domestic efforts for development. This aspect, which has not yet been taken seriously by the DRC, is central to the reform of its educational system and management of its public finances.

Finally, all of this is possible only if ethical behaviours are promoted in public services. ${ }^{107}$ There is a need for the Congolese leadership to respect legal texts they adopt themselves, which is an aspect of human culture for the rule of law. The promotion of ethical behaviours also implies that there should be a value-based public governance focusing on the realization of the collective welfare of Congolese people. This requires a high degree of patriotism to stop the inversion of ethical values which the 2006 Constitution has explicitly stigmatized, including tribalism, corruption, embezzlement, the plundering of resources, the propensity for illicit enrichment and irresponsible state governance. The Congolese leadership must demonstrate that it loves not only the country as such but also its inhabitants.

\section{E. Conclusion}

Congolese law incorporated the right to development after the DRC had accessed the African Charter on Human and Peoples' Rights in 1987 and following protracted crises and armed conflicts which undermined the well-being of the Congolese people in the 1990s. The technique of incorporation relies on the tradition of declaration of human rights in the Congolese constitutions leaving implementation issues to the legislature and the administration. In this regard, several laws, particularly in the sector of exploitation of natural resources (oil, minerals and forest mainly), have been adopted. The synthesis stemming from this legal framework is twofold. On the one hand, the duty to respect the right to development belongs not only to the Congolese state but also to any person pursuant to the 2006 Constitution. The conception of this human right is predominantly socio-economic, individualistic and collective. It is acknowledged to all Congolese, each Congolese, and by extension to all populations living in the territory under the jurisdiction of the Congolese state. On the other hand, efforts made to realize this right include a partnership for development between public and private sectors. This policy has different branches, ranging from the duty to share equitably the national wealth and international cooperation for development to the imposition of the social responsibility of enterprises operating in the DRC.

publique Démocratique du Congo : les défis récurrents de décolonisation et de développement économique et social, Kinshasa, Cedesurk, 2012, pp.1160 - 1163.

106 Assembly/AU/Dec.790( Extra-Ordinary Summit, AU Assembly, Lilongwe (Malawi), $3^{\text {rd }}$ November 2018, para.1.

107 See Elie Phambu Ngoma Binda, Principes de gouvernance éthique ... Et le Congo sera sauvé, Louvain-la Neuve, Academia/Bryulant 2009. 
However, as this study demonstrated, the right to development enshrined in the Congolese law remains more a matter of claims and aspirations than a tangible reality reflecting an increase in the quality of life of the Congolese people. There are many obstacles to the realization and enjoyment of the right to development. These include the adverse effects of capitalist liberalism which has been imposed as the ideological driver of development in the DRC, the paralyzing extraversion of development policies adopted by the government as a consequence of available poor funding at the national level, and the culture of predation which makes the DRC a tool more so for private extraction of resources for personal, familial or foreign enrichment than advancing the welfare of the Congolese people.

To reverse this situation, at least three permissive conditions should be fulfilled: stopping the ongoing statocide or intentional destruction of the state which has intensified since 1993; integrating the DRC's international commitments in domestic development policies which must be based on an internal dynamic putting Congolese in the center of every socioeconomic initiative; and promoting and defending ethical behaviours in public services in order to curb the current perverse inversion of moral values in the society. The Congolese leadership has thus a great responsibility to trigger or impose this much needed change. 